\title{
THE EFFECT OF COMPETITIVE AND GREEN MARKETING STRATEGY ON DEVELOPMENT OF SMES
}

\author{
V. Sathana*1, T. Velnampy ${ }^{2} \&$ S. Rajumesh ${ }^{3}$ \\ ${ }^{1}$ University of Jaffna, vsathana@univ.jfn.ac.lk \\ ${ }^{2}$ University of Jaffna, tvnampy@yahoo.co.in \\ ${ }^{3}$ University of Jaffna, rajumesh3@yahoo.com
}

\begin{abstract}
The purpose of this study is to examine the effect of competitive and green marketing strategy on development of SME in Jaffna district by surveying 302SMEs in Jaffna district. Resource advantage theory of competitions is underpinned to link the marketing strategy and performance development of SMEs. Llittle researches were undertaken into the competitive marketing strategy and green marketing strategy in SMEs in the post war context. The influences of these marketing strategy on the performance of SME is nebulous in the post ear context. Data were collected by using questionnaires from owners of SMEs. Simple random sampling method was applied to select samples for this study. Structural equation method (SEM) was utilized to identify the effect of marketing strategy on the development of SMEs. The findings revealed that competitive marketing strategy significantly influenced on the financial development, customer development and SME development and not significantly influenced on the employee development. Regarding green marketing strategy, it significantly influenced on customer development and employee development not significantly influenced on the financial and SME development. This research suggested that entrepreneurs need to apply these two strategies for the development of SMEs.
\end{abstract}

Key words: competitive marketing strategy, green marketing strategy, development of SMEs

\section{Introduction}

In the Sri Lankan context, the national policy framework for SME development defined SMEs, based on the number of employees and annual turnover (Gunawardana, 2016). The category of Small and Medium sized Enterprises (SMEs) 
was made up of a enterprises which employ less than 300 employees and which have an annual turnover not exceeding Rs. 750 Million (Gunawardana, 2016). This research addressed competitive marketing strategy and green marketing strategy and their influences on the development of SMEs. The Government of Sri Lanka recognizes SMEs as the backbone of the economy, as it accounts for more than $75 \%$ of the total number of enterprises, provides $45 \%$ of the employment and contributes to $52 \%$ of the Gross Domestic Production (GDP) (Gunawardana, 2016). Earlier researcher illustrates that SMEs in pursuit of original goals and performance achievement, do not adopt the marketing concepts to the same extent as large firm and the marketing practices in SME are situation specific and variable, regarding the levels of sophistication and effectiveness (O'Dwyer, Gilmore and Carson, 2009). The small firm owner- managers engage in marketing, but the influence of this marketing on the organization success is not fully understood (O'Dwyer, Gilmore and Carson, 2009). The marketing functions in SMEs are hindered by constraints such as poor cash flow, lack of marketing expertise business size, tactical customer, related problems and strategic related problems. SME sector was seriously affected by nearly three decades of separatist war between 1983 and 2009 in Sri Lanka, post war environment contains destruction of infrastructure, poverty, regional imbalance, low income, poor education, psychological effects on society and women headed families (they are the heads of the families). Jaffna district was seriously affected by the local war (Vijayakumar, 2013; Shivany and Thirunavukkarasu, 2015). After the war, SMEs are managing the situations and slowly improving their conditions. But the national and world trend of SMEs are far away from the condition of SMEs in the post war market in terms of product and market differentiation, focusing of customers, dissemination of information and specially green concern in the productions. Yet, despite such restrictions, the SMEs need to successfully use marketing to generate sales a fact that highlights the need to understand competitive marketing strategy and green marketing strategy as practiced by SMEs and their influence on the development of SME. Consideration is given to the unique characteristics of SMEs and the unique nature of marketing in SMEs in post war, marketing is performed differently in SMEs. Yan and Chew, (2011) suggested competitive marketing strategy is a major one to take competitive advantage and Chahal, Dangwal, and Raina (2014) suggested that green market orientation is very important strategy for SMEs. The effect of Green marketing orientation on the customer satisfaction and employee retention was proved for SMEs in India (Chahal, Dangwal, and Raina, 2014). Differentiation and focus strategy were unique strategy to apply or SMEs (Baker and Hart, 2008) and Cost leadership was 
explored for large firms in the post war market of Northern Province by Shivany and Thirunavukkarasu (2015). Impact of competitive marketing strategy on performance was tested for SMEs in China (Yan and Chew, 2011) and they also produced mixed result as positive and negative. However competitive marketing strategy and green marketing strategy has focused on firm specific SMEs and little research were undertaken into the competitive marketing strategy and green marketing strategy in SMEs in the post war context. Further the influences of these marketing strategy on the performance of SME is nebulous and not empirically tested in the post war context. There is need to link the competitive and green marketing strategy with the development of SME. Therefore, the main aim of this study is to identify the effect of competitive and green marketing strategies on development of SMEs in Jaffna district.

\section{Literature Review}

\section{Competitive Marketing Strategy(CMS)}

The competitive marketing strategy aims to deploy resources and capabilities in the market. Porter (1979) explained that organization can achieve competitive advantage over its rivals: cost advantage and differentiation advantage. Further Porter (1979) identified three strategies that businesses can use to tackle competition. They are cost leadership, differentiation strategy and focus strategy. Cost advantage is at a lesser cost, organization provides the product and services as its competitors. Shiv any and Thirunavukkarasu (2015) described that in the post war market, large firm is essential to follow cost leadership strategy to compete with national and international brands. Differentiation advantage differentiates product or services offered by organization than its competitors. Market and product differentiation are effective form of marketing strategy for SMEs (O'Dwyer, Gilmore and Carson, 2009; Baker and Hart, 2008). O'Dwyer, Gilmore and Carson, (2009) mentioned that differentiation includes product differentiation for each segments, enhancement and modifications. Focus strategy ideally tries to get businesses to aim at a few target markets and this strategy is often used for smaller businesses since they may not have the appropriate resources or ability to target everyone (Baker and Hart, 2008). Yan and Chew (2011) expressed that focusing strategy provide SMEs some potential for creating competitive advantage and achieve superior performance for SMEs. Baker and Hart, (2008) denoted that though differentiation and focus strategy were mentioned as competitive strategy, these concepts were based on the concept of marketing. Julien (2000) explained that advertising is a major competitive strategic tool to inform about products, persuade 
target audience to purchase by promotions and sell directly to customers. Advertising strategy is suggested as marketing strategy for post war market of Northern Province strategy to disseminate information (Shivany and Thirunavukkarasu, 2015). Differentiation and focus strategy were denoted as competitive marketing strategy by Yan and Chew, (2011), cost leadership and advertising were suggested as marketing strategy by Shivany and Thirunavukkarasu (2015).

\section{Green Marketing Strategy (GMS)}

Earlier researchers revealed dimension of green marketing strategy, namely, green purchasing, manufacturing, green process, waste disposal and green supply chain (Koner and Cohen, 2001). Green purchase is denoted as the probability and willingness of a person to give preference to products that are having eco-friendly features over other traditional products in their purchase considerations. Green purchasing includes use biodegradable, recyclable materials, contamination-free and green materials, purchase safety certified materials, do not use toxic, harmful ingredients, or in decomposable materials (Wu and Lin, 2016). Firms use natural resources for their production process and reuse most of the wastages from this productions. The green manufacturing firms use natural resources, reduce pollution and waste, recycle and reuse materials, and moderate emissions in their processes ( $\mathrm{Wu}$ and Lin, 2016). Companies consider green aspect in the pricing, create awareness about their green product to customers through green process and remove and handle wastages of firms through this process. Firms encompass all activities related to product modification, changes to production process, packaging changes, as well as modifying advertising, green marketing process includes use of cleaner technology, use of ecological materials, urges customers to take environmental actions, the firm selects cleaner transportation method, holds awareness seminars for customers and implement natural environmental programs (Chahal, Dangwal and Raina, 2014). Organizations apply wide range of green marketing activities for their nature of business. Firms clearly explained their feature of green products to customers advertising and promotional activities which is through green process. Manufacturing firms use natural raw material and packaging material which positive health effect and environmental effects (Chahal, Dangwal and Raina, 2014). In the case of green purchasing and manufacturing, companies purchase green raw material for productions and packaging. Green supply chain management consists of uses ISO certification on quality, redefines operation and production processes, uses recyclable or reusable containers, requires commitment from senior managers and environmental 
management systems (Chahal, Dangwal and Raina, 2014).Further Green supply chain concerns the green transportation and delivery (Wu and Lin, 2016).

\section{Development}

Development is commonly explained as the process in which someone or something grows or changes and becomes more advanced (Beard, 2000) and gradual growth of something in organization (Cook, 1998). Lavric, (2010) focused on the identification of the most relevant tendencies in the SMEs sector from the perspective of six indicators namely, the number of enterprises (branches), the number of persons employed, the rate of profitability, gross value added, labour productivity and the propensity to invest. Cacioppe (2000) suggested balance score card measurement model for organization development. Kaplan and Norton (1992) introduced Balanced Scorecard (BSC) measurement system. Habbard (2009) developed balance scorecard performance measurement system with the stakeholder theory. Development measurement of this study covered balance scorecard measurement and SME development indicators.

Financial performance, customer performance, employee development and SME development indicators were considered as major elements for this research (Habbard, 2009, Lavric, 2010, Yongvanich and Guthrie, 2006, Cacioppe, 2000; Olaru et al., 2010). Financial performance measures cover cash flow, total revenue, return on equity, return on assets, leverage ratio and liquidity ratio (Tsai and Chou, 2009, Habbard, 2009). Customer performance encourages the identification of measures important to our customers as number of new customers, customer retention rate, on time delivery, share of important customer purchases, customer satisfaction and ranking by important customers (Yongvanich and Guthrie, 2006). Employees' development was foundation for organization (SME) development which includes sustainable job and benefit, worker development and leadership (Cacioppe, 2000; Olaru et al., 2010; Yongvanich and Guthrie, 2006). Sustainable job and benefit includes quality of work life, employee happiness, employee retention and implementation of employee suggestions (Habbard, 2009). Worker development emphasizes the teamwork and group work, employee involvement, learning through training, and productivity (Olaru et al., 2010). Leadership includes employee care, equal and fair treatment, building the confidence and information to employees (Yongvanich and Guthrie, 2006). SME development indicators included the development of number of branches or sales centers, number of employees, turnover, 
capital growth, new product introductions and advances in technical and marketing competences (Lavric, 2010, Navickas and Malakauskaite, 2009).

\section{Conceptual Model of the Study}

Strategy plays a central role to determine firm performance (Yan and Chew, (2011).The resource-advantage (R-A) theory of competition is an economic tool used to determine the strategic resources available to a firm (Hunt and Morgan, 1995). Resources are defined as the tangible and intangible resources. Marketing strategy is an intangible resource of firms. Each firm in the market place will have at least some resources that are unique to it that could constitute a comparative advantage in resources and could lead to positions of competitive advantage in the market place. Market place positions of competitive advantage then result in superior financial performance. SMEs have limited and unique resources which create comparative advantage by applying competitive and green marketing strategy and achieve market position. In this study, the resource advantage theory was underpinned to link the competitive marketing strategy and green marketing strategy with the development of SMEs.

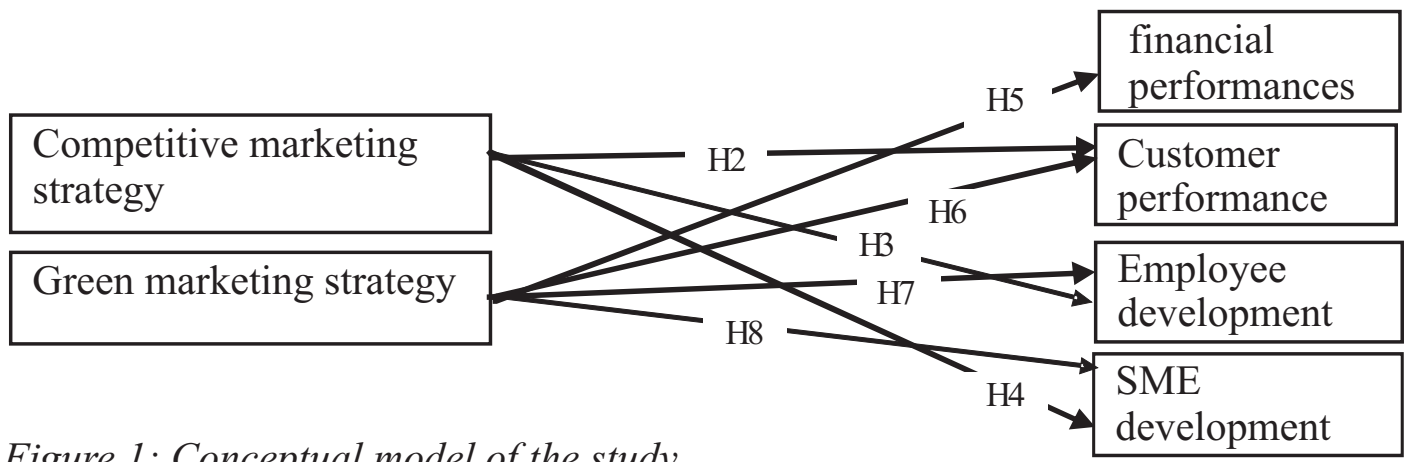

Figure 1: Conceptual model of the study

\section{Hypotheses Development}

\section{CMS and Development of SMES}

SMEs possess limited resources and capabilities, high flexibility and few decision makers Baker and Hart, 2008). Because of high flexible, they are capable to differentiate easily their product and market without any restrictions. SMEs apply differentiation and focus strategy to satisfy selected group of customers and make more profit (Yan and Chew, 2000). The manufacturing SMEs disseminate information through advertising and high reach created more sales revenue. SMEs rely heavily on 
developing marketing differentiation and focus in order to be sustainable in the industry and to achieve competitive advantage and success. Focusing on a market segment could make a SME to gain exclusive experience of the conditions and in turn improves its responsiveness with less cost, which leads to more return on investment. Thus focus strategy may provide SMEs some potential for creating competitive position. Differentiation strategy through ancillary intangibles may prove effective to achieve success for small firms in China (Yan and Chew, 2000). Focus on a customization develops market towards the profitable and potential customer, and creates more customer satisfaction and retention (O'Dwyer, Gilmore and Carson, 2009). Product awareness through advertising creates more new customers for organizations, other promotions try to keep customers with organization (Shivany and Thirunavukkarasu, 2015; Julien, 2000). SMEs keep customers by offering different product to different market. Firms interested in the product and market differentiation which induce employees to develop, learn and apply new idea, highly involve in the work, more training and development and people oriented leadership to words employees according to the skill and talent of employees (O'Dwyer, Gilmore, and Carson, 2009.) Product differentiation and market differentiation induced to invest more money and productivity in business and create more branches (Yan and Chew, 2011). The manufacturing SMEs should rely heavily on developing marketing differentiation and focus in order to be sustainable in the industry and to achieve competitive advantage and success. Focusing on a market segment could make a SME to gain exclusive experience of the conditions and in turn improves its responsiveness. Thus focus strategy may provide SMEs some potential for creating competitive advantage.

\section{Hence we Propose the Following Hypotheses:}

H1: Competitive marketing strategy impacts on the financial performance of manufacturing SMEs in Jaffna district

H2: Competitive marketing strategy impacts on the customer performance of manufacturing SMEs in Jaffna district

H3: Competitive marketing strategy impacts on the employee development of manufacturing SMEs in Jaffna district

H4: Competitive marketing strategy impacts on the SME development of manufacturing SMEs in Jaffna district 


\section{GMS and Development of SMEs}

The green marketing strategies influence on business performance of organic farms in Taiwan (Wu and Lin, 2016). Cronin et al. (2011) explained that green marketing strategies become increasingly more important to firms adhering to a triple-bottom line performance evaluation. Private organization achieves ultimate goal of financial success and address satisfy various stakeholder through the green marketing applications (Cronin et al., 2010). Firm produces innovative green products, which satisfy customers, retain them continuously with firms. Green marketing offers green image which leads to successful and continuous demand for the green products and increase customer satisfaction. Green market strategy offerings make the positive image, firms earn more financial benefits (Wagner and Hansen,2005), which lead to increase employee commitment (Maignan and Ferrell, 2005), trainings and other career development. Green marketing strategy induces to invest more in green aspects, new innovative products, increase number of employees and branch development (Baker and Sinkula, 2005). Ultimately green marketing strategy contributes a significant a role for the firms' to survive in the competitive market ( $\mathrm{Wu}$ and Lin , 2016; Chahal, Dangwal and Raina, 2014). Ottoman (2011) mentioned that firms induce green product, create goodwill for products and improve customer satisfaction, financial success and employee performance. Manufacturing firms use natural raw material and packaging material which have positive health effect and environmental effects. Financial success is considered with the positive manner towards natural environment, when organization involves in all activities as product modifications, packaging, distribution and wastage removals.

Hence we Propose the Following Hypotheses:

H5: Green marketing strategy impacts on the financial performance of manufacturing SMEs in Jaffna district

H6: Green marketing strategy impacts on the customer performance of manufacturing SMEs in Jaffna district

H7: Green marketing strategy impacts on the employee development of manufacturing SMEs in Jaffna district

H8: Green marketing strategy impacts on the SME development of manufacturing SMEs in Jaffna district 


\section{Research Methodology}

Quantitative analysis techniques was employed to test causal relationships between the constructs in the conceptual model. In this study, a survey strategy was deemed to be suitable for data collection. Unit of analysis was the manufacturing SMEs in Jaffna district. There were 2341 SMEs in Jaffna district (IDB Report, 2016). Simple random sampling method was adopted to select respondent from the list of SMEs in the Jaffna district. Respondent were the owners or managers of SMEs. Initially the questionnaires were issued to 350 owners of manufacturing SMEs operating in Jaffna district, but 302 questionnaire were returned. Sample size is adequate comparing with the population of this study (Sekaran and Bougie, 2010). The items used to measure competitive marketing strategy, green marketing strategy, financial performance, customer performance, employee development and SME development were derived from literature review and models of earlier researches. Competitive marketing strategy (CMS) includes differentiation (Yan and Chew, 2011; Porter, 1979), focus (Yan and Chew, 2011; Porter, 1979), cost leadership (Porter, 1979, Shivany and Thirunavukkarasu, 2015) and promotion (Julien, 2000; Shivany and Thirunavukkarasu, 2015). Green marketing strategy includes green purchasing and manufacturing, green process and waste disposal and green supply chain (Wu and Lin, 2016; Chahal, Dangwal and Raina 2014; Cronin et al. 2011). Development includes financial performance, customer performance, employee development (Karabulut, 2015; Tsai and Chou, 2009) and SME development (Yan. and Xu, 2006; Lavric, 2010). In case of small scale industry, where published data is not available and respondents are generally reluctant to release objective fact and figures to outsiders, subjective measurement through primary sources of data collection is only viable option for measurement of business performance (Vij and Bedi, 2016). Employee development includes sustainable job and benefits, worker development and leadership (Prud' homme and Raymond, 2016; Olaru et al, 2010, Stubble field Loucks, et al., 2010; Yang and $\mathrm{Xu}, 2006)$. The items generated for variables were based on a five point scale ( $1=$ strongly disagree, $5=$ strongly agree). The finalized instrument comprised fourteen items for CMS, eleven items for GMS, six for financial development, five for customer performance, eleven item for employee development and six item for SME development. The research instrument was finalized after pretesting it using qualitative and quantitative approaches. The content validity of the each items were ensured by the literature, interview with mangers of SMEs and open discussion with subject experts. Pretest was conducted on 30 SME owners operating in manufacturing SMEs. 


\section{Data Analysis}

Demographic profile

Data survey planned to 350 respondents (SMEs), the response rate was $86 \%$ (302 respondents). The profile of sample was explained by the table 1 .

\section{Table 1: Demographic Profile of Samples}

\begin{tabular}{|l|l|l|}
\hline & $\begin{array}{c}\text { Number of } \\
\text { respondent }\end{array}$ & $\begin{array}{c}\text { Respondent in } \\
\%\end{array}$ \\
\hline Business registration & & $91 \%$ \\
\hline Yes & 275 & $9 \%$ \\
\hline No & 27 & \\
\hline Education of owners & & $7 \%$ \\
\hline Ordinary level & 21 & $51 \%$ \\
\hline Advance level & 154 & $15 \%$ \\
\hline Graduate & 45 & $27 \%$ \\
\hline Postgraduate & 82 & $8 \%$ \\
\hline Annual income & & $30 \%$ \\
\hline Below Rs 300,000 & 25 & $52 \%$ \\
\hline Rs $300,000 \leq 500,000$ & 91 & $7 \%$ \\
\hline Rs $500,001 \leq 1,000,000$ & 158 & $1 \%$ \\
\hline Rs $1,000,001 \leq 50,000,000$ & 22 & \\
\hline Above Rs $50,000,000$ & 6 & \\
\hline
\end{tabular}

In this study, Most of the SMEs were registered (91\%), and only 9\% of SMEs were not registered. Further the $7 \%$ of entrepreneurs studied ordinary level, 51\%of the entrepreneurs studied advance level $15 \%$ graduated and $27 \%$ post graduated. Most of the owners studied advance level education. Regarding the annual income, $8 \%$ earned below 300,000 and $30 \%$ earned between 300,000 and 500000, 52\% earned between 500,001 and $10000007 \%$ earned between 1 and 5 million and $1 \%$ earned above 50 million as annual income. 


\section{Reliability Analysis}

Reliability is the measure of how consistency a scale will give the same response, if data are collected at different points in time (Hair \& Anderson, 2010). The cut-off point of Cronbach's alpha coefficient of a scale should be above 0.7 or 0.5 (Nunnally, 2010).

\section{Table 2: Reliability scores of construct of the conceptual model}

\begin{tabular}{|l|c|}
\hline \multicolumn{1}{|c|}{ Construct } & Cronbach's alpha Coefficient \\
\hline Differentiation & 0.822 \\
\hline Cost leader ship & 0.635 \\
\hline Focus & 0.800 \\
\hline Advertising(Promotions) & 0.622 \\
\hline Green purchasing and manufacturing & 0.806 \\
\hline Green process and waste disposal & 0.600 \\
\hline Green supply chain & 0.603 \\
\hline Financial development & 0.872 \\
\hline Customer development & 0.871 \\
\hline Sustainable job and benefits & 0.613 \\
\hline Worker development & 0.834 \\
\hline Leadership & 0.656 \\
\hline SME development & 0.812 \\
\hline
\end{tabular}

Cronbach's alpha coefficients for all the constructs were above 0.60 . The internal consistence of every construct was within the acceptable limits.Kaiser (1974) recommends that the accepted index of KMO \& Bartlett's Test of Sphericity should be over 0.5. Also The KMO value is 0.845 with Barlett's test of Sphericity (BTS) coefficient 0.000 . Hence, data indicate the suitability and appropriateness.

\section{Normality of the Variable}

Normality implies that data distribution for an individual construct fits with the shape of normal distribution (Levine, Krehbiel, Berenson and Viswanathan, 2010). If the distribution of a dataset varies significantly from normality, the results of multivariate analyses would be invalid (Hair \& Anderson, 2010 and Sekaran \& Bougie, 2010). Skewness and kurtosis values of a data distribution are widely applied to determine normality of a data set. In this method, normality of a data distribution is assumed, if 
statistical values of skewness or kurtosis are within the value \pm 2.00 (Hair \& Anderson, 2010). Skewness and kurtosis values of all study constructs were below 2.0 and which were presented in Table 3

Table 3: Skewness and Kurtosis Values of Study Constructs

\begin{tabular}{|l|c|c|}
\hline \multicolumn{1}{|c|}{ Variables } & Skew & Kurtosis \\
\hline Differentiation & .427 & -1.106 \\
\hline Focus & .629 & -.155 \\
\hline Promotions & .906 & .803 \\
\hline Green purchasing and manufacturing & 1.678 & 1.294 \\
\hline Green supply chain & .860 & .626 \\
\hline Financial development & .901 & .282 \\
\hline Customer development & 1.878 & 1.986 \\
\hline Worker development & .901 & .282 \\
\hline Leadership & .529 & -.165 \\
\hline SME development & .640 & 371 \\
\hline
\end{tabular}

\section{Confirmatory Factor Analysis}

CFA was performed initially factor-wise on each of the independent and dependent variables (Hair \& Anderson, 2010). Both measurement estimates and structural estimates were examined for overall model fitness as recommended by Hair \& Anderson (2010).

\section{Result of Measurement Model}

First Order CFA Result

CMS has four dimension as differentiation, cost leadership, focus and promotion. Fourteen item were assigned to CMS. Low factor loading $(<0.5)$ of four items were deleted. Balance ten items were moderate to high factor leading (Table 3). Another variable green marketing strategy consists of 11 items, five items were deleted by the low factor loading. Balance six items were moderate to high factor loadings (Table 3 ). One item from the financial development, two item from customer performance, four items from employee development and one from SME development were deleted by low factor loadings. Balance items were moderate and high factor loadings. 
Table 3: First order CFA Result

\begin{tabular}{|c|c|c|c|c|c|}
\hline Items & & SRW & AVE & $\mathrm{CR}$ & Model fit \\
\hline \multicolumn{6}{|l|}{ Differentiation } \\
\hline Product quality & D1 & 0.85 & .75 & .90 & $\mathrm{CMIN} / \mathrm{df}=3.253$ \\
\hline Innovative product features & $\mathrm{D} 2$ & 0.87 & & & $\mathrm{NFI}=0.911$ \\
\hline product customization (tailor-made products) & D3 & 0.89 & & & $\mathrm{CFI}=0.936$ \\
\hline Cultural match & D4 & 0.86 & & & RMSEA $=0.08$ \\
\hline Focus & & & & & $\mathrm{GFI}=0.879$ \\
\hline Selected market & F1 & 0.88 & .59 & .67 & $\mathrm{AGFI}=0.846$ \\
\hline Market leadership & $\mathrm{F} 2$ & 0.82 & & & \\
\hline innovate products/services & $\mathrm{F} 3$ & 0.58 & & & \\
\hline \multicolumn{6}{|l|}{ Advertising ( promotion) } \\
\hline Adequate awareness & AP1 & 0.60 & .38 & .53 & \\
\hline Adequate promotions & AP2 & 0.71 & & & \\
\hline Personal selling & AP3 & 0.53 & & & \\
\hline \multicolumn{6}{|l|}{ Green purchasing and manufacturing } \\
\hline Use biodegradable recyclable materials & GPM1 & 0.882 & .77 & .81 & \\
\hline Use natural products & GPM1 & 0.857 & & & \\
\hline Avoid producing waste matter, wastewater, exhaust gas & GPM3 & 0.898 & & & \\
\hline \multicolumn{6}{|l|}{ Green supply chain } \\
\hline commitment from senior managers & GSC1 & 0.621 & .55 & .72 & \\
\hline reduce energy consumption & GSC2 & 0.888 & & & \\
\hline greenhouse gas emission and low energy & GSC3 & 0.680 & & & \\
\hline \multicolumn{6}{|l|}{ Financial performance } \\
\hline Cash flow & FP1 & 0.805 & .46 & .82 & \\
\hline Total revenue & FP2 & 0.875 & & & \\
\hline Return on equity & FP3 & 0.577 & & & \\
\hline Gross profit & FP4 & 0.551 & & & \\
\hline Return on assets & FP5 & 0.508 & & & \\
\hline \multicolumn{6}{|l|}{ Customer performance } \\
\hline Number of new customers & $\mathrm{CP} 1$ & 0.86 & .66 & .79 & \\
\hline Customer retention rate & $\mathrm{CP} 2$ & 0.77 & & & \\
\hline Customer satisfaction through on time delivery & CP3 & 0.80 & & & \\
\hline \multicolumn{6}{|l|}{ SME development } \\
\hline Increased of branches or sales centers & S1 & 0.856 & .67 & .92 & \\
\hline Number of employees & $\mathrm{S} 2$ & 0.873 & & & \\
\hline Turnover & S3 & 0.791 & & & \\
\hline Capital growth & S4 & 0.779 & & & \\
\hline New product introductions & S5 & 0.790 & & & \\
\hline \multicolumn{6}{|l|}{ Worker development and training } \\
\hline Employee involvement & WP1 & 0.742 & .65 & .95 & \\
\hline productivity & WP2 & 0.813 & & & \\
\hline $\begin{array}{l}\text { promoting to constructive group/ team work } \\
\text { developing multi-skilled and new method }\end{array}$ & WP3 & 0.862 & & & \\
\hline by initial and continuous training & WP4 & 0.800 & & & \\
\hline Leadership & & & .41 & .77 & \\
\hline Employee care & LEA1 & 0.564 & & & \\
\hline Equal and fair treatment, & LEA2 & 0.807 & & & \\
\hline Building the confidence & LEA3 & 0.513 & & & \\
\hline
\end{tabular}


The CFA has a CMIN / df value of 3.253 and it is below the cutoff point. Also fit indices CFI, GFI, NFI and AGFI are close to 0.9. Additionally, RMSEA value is as cutoff points. These indices suggest a good model approximation to the sample data (Table $3)$.

All items of marketing strategy and development of SMEs are above than 0.5 of standardized regression weight. AVEs of "financial performance and leadership" are" 0.46 and 0.41 " respectively which are close to 0.5. Even AVE of advertising (promotions) and learning is 0.38 , factor loadings of items to advertising and promotion are above 0.50 . Moreover, there was no significant improvements in model fit indices when deleting construct of advertising and promotion. All other AVE values of constructs are above 0.5 . The value of construct reliability of all factors are above than 0.7 except the advertising with 0.53 (table 8 ). These measures ensured the validity of the factors which were adopted to the model. First order measurement of model was given in the figure 1.The standardized regression weight (SRW) of items lie between 0.508 and 0.894 (Table 3 ).

Table 4: Discriminant Validity of Constructs

\begin{tabular}{|l|l|l|l|l|l|l|l|l|l|l|}
\hline & DIF & FOC & AP & GMP & GSC & FP & CP & SMED & WP & LEA \\
\hline DIF & $\mathbf{0 . 8 7}$ & & & & & & & & & \\
\hline FOC & 0.65 & $\mathbf{0 . 7 7}$ & & & & & & & & \\
\hline AP & 0.57 & 0.59 & $\mathbf{0 . 6 2}$ & & & & & & & \\
\hline GMP & 0.77 & 0.62 & 0.50 & $\mathbf{0 . 8 8}$ & & & & & & \\
\hline GSC & 0.76 & 0.74 & 0.52 & 0.69 & $\mathbf{0 . 7 4}$ & & & & & \\
\hline FP & 0.69 & 0.67 & 0.65 & 0.61 & 0.67 & $\mathbf{0 . 6 8}$ & & & & \\
\hline CP & 0.60 & 0.77 & 0.60 & 0.76 & 0.74 & 0.69 & $\mathbf{0 . 8 1}$ & & & \\
\hline SMED & 0.75 & 0.72 & 0.52 & 0.78 & 0.60 & 0.68 & 0.73 & $\mathbf{0 . 8 2}$ & & \\
\hline WP & 0.75 & 0.67 & 0.44 & 0.70 & 0.72 & 0.71 & 0.72 & 0.75 & $\mathbf{0 . 8 1}$ & \\
\hline LEA & 0.52 & 0.52 & 0.61 & 0.44 & 0.48 & 0.46 & 0.53 & 0.50 & 0.38 & $\mathbf{0 . 6 4}$ \\
\hline
\end{tabular}

The discriminant validity for most of the constructs is achieved when a diagonal value, square root of AVE (in bold) is higher than the values in its row and column. All the factors are high discriminant validity which was given in the table 4 . 


\section{Result of Structural Model and Hypotheses Testing}

\section{CMS and Financial Development}

The CMIN / df, CFI, RMSEA and NFI values for the CMS and GMS - development of SME model are 3.246, 0.912, 0.078 and 0.901 respectively, showing high model fit (Table 5).

\section{Table 5: Structural model validity}

\begin{tabular}{|l|l|c|}
\hline \multicolumn{1}{|c|}{ Name of index } & Level of acceptance & Model fit indices \\
\hline Chi-Square & P-value $>0.05$ & 0.000 \\
\hline RMSEA & RMSEA $<0.08$ & 0.078 \\
\hline GFI & GFI $>0.90$ & 0.871 \\
\hline AGFI & AGFI $>0.90$ & 0.840 \\
\hline CFI & CFI $>0.90$ & 0.912 \\
\hline NFI & NFI $>0.90$ & 0.901 \\
\hline Chisq/df & Chi-Square/ df $<5.0$ & 3.246 \\
\hline
\end{tabular}

\section{Result of Hypotheses Testing}

The study show that competitive marketing strategy has a significant and positive influence on financial performance (0.757), customer performance (0.653) and SME development (0.525) of SM and not significant influence on the employee development (figure 2). Green marketing strategy significantly influence on the customer performance ( 0.544 ) and employee development (0.794) but insignificantly influence on the financial performance and SME development. 


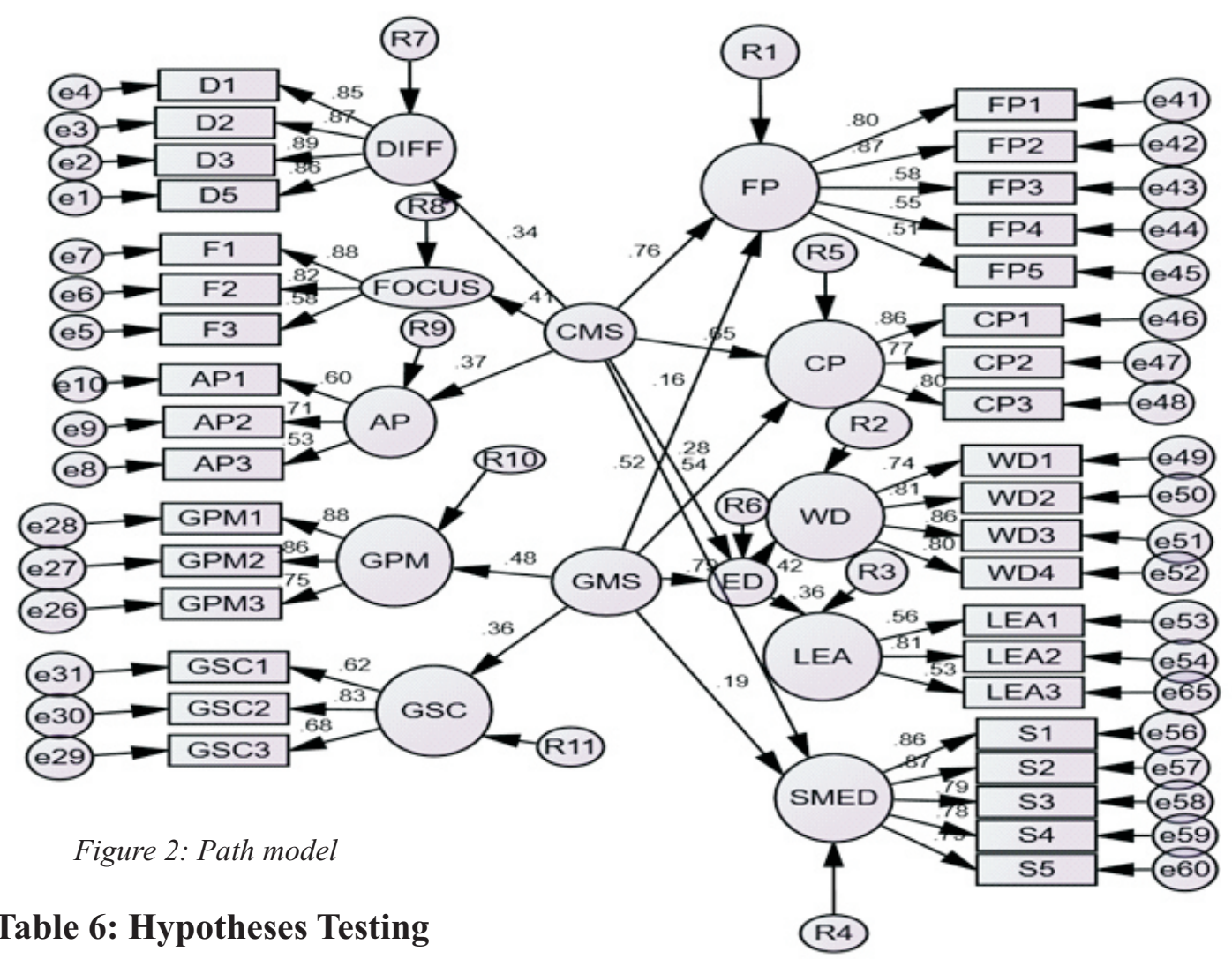

\begin{tabular}{|c|l|l|l|}
\hline Hypotheses & SRW & Sig. & Conclusion \\
\hline $\begin{array}{c}\text { H1: Competitive marketing strategy impacts on the financial } \\
\text { performance of manufacturing SMEs in Jaffna district }\end{array}$ & 0.757 & 0.000 & Accepted \\
\hline $\begin{array}{c}\text { H2: Competitive marketing strategy impacts on the customer } \\
\text { performance of manufacturing SMEs in Jaffna district }\end{array}$ & 0.653 & 0.001 & Accepted \\
\hline $\begin{array}{c}\text { H3: Competitive marketing strategy impacts on the employee } \\
\text { development of manufacturing SMEs in Jaffna district }\end{array}$ & 0.284 & 0.245 & Rejected \\
\hline $\begin{array}{c}\text { H4: Competitive marketing strategy impacts on the SME } \\
\text { development of manufacturing SMEs in Jaffna district }\end{array}$ & 0.525 & 0.000 & Accepted \\
\hline $\begin{array}{c}\text { H5: Green marketing strategy impacts on the financial } \\
\text { performance of manufacturing SMEs in Jaffna district }\end{array}$ & 0.160 & 0.474 & Rejected \\
\hline $\begin{array}{c}\text { H6: Green marketing strategy impacts on the customer } \\
\text { performance of manufacturing SMEs in Jaffna district }\end{array}$ & 0.544 & 0.000 & Accepted \\
\hline $\begin{array}{c}\text { H7: Green marketing strategy impacts on the employee } \\
\text { development of manufacturing SMEs in Jaffna district }\end{array}$ & 0.794 & 0.021 & Rejected \\
\hline $\begin{array}{c}\text { H8: Green marketing strategy impacts on the SME } \\
\text { development manufacturing SMEs in Jaffna district }\end{array}$ & 0.190 & 0.325 & \\
\hline
\end{tabular}




\section{Discussion and Implication}

The present study considered owners/ managers of the SMEs (Manufacturing) operating in Jaffna district. The study was undertaken on competitive and green marketing strategy on the development of SMEs. Even four dimensions were adopted, the finding confirmed three dimensions of CMS construct. Unlike the dimension construct of earlier studies and theories (Yan and Chew,2011; Porter,1979), this study established three appropriate dimensions of CMS, namely, differentiation, focus and promotions. These dimensions were quite significant in the context of manufacturing SMEs. The differentiation consists of four items, moderate contribution was proved by quality, innovative features, product customization and culture match. The SMEs try to produces quality products, most of their products are handmade with innovative features, SMEs directly communicate with customers and fulfill the needs of customer, and consider their culture to produce the products. Second factor loaded moderate contribution, namely, focus strategy consists of three items as selected market, market leadership and innovative products for selected market. SMEs consists of $90 \%$ of micro business. Most of the micro producers focus on a selected market, produces innovative and unique products for that selected market and try to access the market leadership in the selected market. Another dimension of promotion included that SMEs advertise to create awareness and induce to purchase, promote and induce customer to purse and have personnel selling to sell their products. CMS has significant positive impact on the financial, customer and SME development. So the study establishes that firms can induce the development through adopting CMS. Over all strong contribution of CMS is on financial and growth of SMEs and moderate impact of CMS on customer development. The result indicate that the firms that adopt the phenomena of competitive marketing in their activities can ultimately develop the SMEs.

This present study considered GMS with three dimension for Manufacturing SMEs, namely green purchasing and manufacturing, green process and waste disposal, and green supply chain, these are gathered from earlier studies (Wu and Lin, 2016, Chahal, Dangwal and Raina, 2014). Two dimensions were average significant, namely green purchasing and manufacturing and green supply chain. SMEs urges to use biodegradable recyclable materials, use natural resources, avoid to produce waste matter, water and exhaust gas, reduce energy consumption, maintain green gas emission and low energy consumption and manger have higher commitment towards the greener productions. Use of bio - degrable recyclable material and use of natural 
product have high contribution, this means SMEs uses environmental friendly raw materials as much as possible. Commitment from SMEs' managers for green productions is average contribution, further reduce energy consumption, avoid for producing waste matter, waste matters and exhaust gas, reduce energy consumption and greenhouse gas emission is also average contribution by SMEs. GMS has significant impact on customer development and employee development. This study reveals that SMEs induce their development through adopting environmentally friendly marketing strategy. From overall perspective there is strong contribution of CMS and GMS on the development of SMEs.

\section{Implications}

National and international competitions for SMEs creates challenging environment in Jaffna district. Measuring CMS is considered to manage these competitive pressure of SMEs. Our study findings have implications for pragmatic applications marketing strategy for of SMEs. GMS is considered one of today's pressing issues for manufacturing SMEs both globally and as nationally. GMS is a key approach in the comprehensive development of the organizations and important strategies for manufacturing SMEs. SMEs associate green concerns in the purchasing manufacturing and delivery and supply of goods. As Earlier researches (Chahal, Dangwal and Raina, 2014; Koner and Cohen, 2001) stressed this study establish firm must take an initiative to understand the role of green marketing strategy and its long run impact on the development of SME. The SMEs efforts in the CMS are established in the study but cost leadership can be successful by limited resource capacity of SMEs. GMS adoptive for SMEs, at the same time SMEs unable to adopt green process because unable to use of cleaner technology and urges customers to take create. In the case of recycle and reuse of unwanted industrial products and substances, government must create infrastructure to adopt green perspectives for SMEs. 


\section{References}

Baker, M. and Hart, S., 2008. The marketing book. Routledge.

Baker, W.E. and Sinkula, J.M., 2005. Environmental marketing strategy and firm performance: Effects on new product performance and market share. Journal of the academy of marketing science, 33(4), pp.461-475.

Beard, M., 2000. Organizational development: An EAP approach. Employee Assistance Quarterly, 16(1-2), pp.117-140.

Cacioppe, R., 2000. Creating spirit at work: re-visioning organization development and leadership-Part I. Leadership \& Organization Development Journal, 21(1), pp.48-54.

Chahal, H., Dangwal, R. and Raina, S., 2014. Conceptualization, development and validation of green marketing orientation (GMO) of SMEs in India: a case of electric sector. Journal of Global Responsibility, 5(2), pp.312-337.

Cook, M.J., 1998. Quality improvement through organizational development. Total Quality Management, 9(4-5), pp.35-37.

Cronin, J.J., Smith, J.S., Gleim, M.R., Ramirez, E. and Martinez, J.D., 2011. Green marketing strategies: an examination of stakeholders and the opportunities they present. Journal of the Academy of Marketing Science, 39(1), pp.158174.

Gunawardana,D,P,. 2016, National Policy Framework for SME Development. Web:www.industry.gov.lk

Hair,J.F., \& Anderson R.E. 2010, Multivaraite Analysis. Higher Education, 7th Ed Hubbard, G., 2009. Measuring organizational performance: beyond the triple bottom line. Business strategy and the environment, 18(3), pp.177-191.

Hudson, M., Smart, A. and Bourne, M., 2001. Theory and practice in SME performance measurement systems. International journal of operations \& production management, 21(8), pp.1096-1115.

Hunt, S.D. and Morgan, R.M., 1995. The comparative advantage theory of competition. The Journal of Marketing, pp.1-15.

IDB, 2016. Internal Reports of Industrial development Board.

Julian, C.C. and O'Cass, A., 2004. The antecedents of export marketing performance: an Australian perspective. Journal of Asia Pacific Marketing, 3(2), p.99.

Kaiser, H. F. 1974. An index of factorial simplicity. Psychometrika, 39(1), 31-36.

Kaplan, R.S. and Norton, D.P., 1992. Measures that drive performance. Harvard Business Review. 
Karabulut, A.T., 2015. Effects of innovation strategy on firm performance: a study conducted on manufacturing firms in Turkey. Procedia-Social and Behavioral Sciences, 195, pp.1338-1347.

Koner, S. and Cohen, M.A., 2001. Does the market value environmental performance. The Review of Economics and Statistics, 83(2), p.281.

Lavric, V., 2010. The Development of the SMEs Sector in Romania. An Approach Regarding the Dynamics and the Perspectives. Review of International Comparative Management, 11(5), pp.931-939.

Levine, D. M., Krehbiel, T. C., Berenson, M. L. and Viswanathan, P. K. (2010) Business Statistics: A First Course (Pushp: Kindersley).

Maignan, I., Ferrell, O.C. and Ferrell, L., 2005. A stakeholder model for implementing social responsibility in marketing. European journal of marketing, 39(9/10), pp.956-977.

Navickas, V. and Malakauskaite, A., 2009. The impact of clusterization on the development of small and medium-sized enterprise (SME) sector. Journal of Business Economics and Management, 10(3), pp.255-259.

Nunnally, J. C. 2010. Psychometric Theory (3 ed.). Noida, India: Tata McGraw-Hill Education.

O'Dwyer, M., Gilmore, A. and Carson, D., 2009. Innovative marketing in SMEs. European Journal of Marketing, 43(1/2), pp.46-61.

Olaru, M., Dinu, V., Stoleriu, G., Şandru, D. and Dinca, V., 2010. Responsible commercial activity of SMEs and specific values of sustainable development in terms of the European excellence model.

Ottman, J.A., Stafford, E.R. and Hartman, C.L., 2006. Avoiding green marketing myopia: Ways to improve consumer appeal for environmentally preferable products. Environment: Science and Policy for Sustainable Development, 48(5), pp.22-36.

Porter, M.E., 1979. How competitive forces shape strategy. Strategic Planning: Readings, pp.102-117.

Prud'homme, B. and Raymond, L., 2016. Implementation of sustainable development practices in the hospitality industry: A case study of five Canadian hotels. International Journal of Contemporary Hospitality Management, 28(3), pp.609-639.

Sekaran, U., Bougie,. 2010. Research methods for business: A skill building approach. 
Shivany, S. and Thirunavukkarasu, V. 2015. Grounded Theory as a Methodology for Exploring Marketing Strategies for a Special Context. SSRN: https://ssrn.com/abstract=3029153

Stubblefield Loucks, E., Martens, M.L. and Cho, C.H., 2010. Engaging small-and medium-sized businesses in sustainability. Sustainability Accounting, Management and Policy Journal, 1(2), pp.178-200.

Tsai, W.H. and Chou, W.C., 2009. Selecting management systems for sustainable development in SMEs: A novel hybrid model based on DEMATEL, ANP, and ZOGP. Expert systems with applications, 36(2), pp.1444-1458.

Vij, S. and Bedi, H.S., 2016. Are subjective business performance measures justified? International Journal of Productivity and Performance Management, 65(5), pp.603-621.

Vijayakumar, S., 2013. Small and Medium Enterprise Promotions for their Growth in Sri Lanka. International Journal on Global Business Management \& Research, 1(2), p.46.

Wagner, E.R. and Hansen, E.N., 2005. Innovation in large versus small companies: insights from the US wood products industry. Management Decision, 43(6), pp.837-850.

Wu, S.I. and Lin, S.R., 2016. The effect of green marketing strategy on business performance: a study of organic farms in Taiwan. Total Quality Management $\&$ Business Excellence, 27(1-2), pp.141-156.

Yan, S. and Chew, D.A., 2011. An investigation of marketing strategy, business environment and performance of construction SMEs in China. African Journal of Business Management, 5(6), p.2396.

Yongvanich, K. and Guthrie, J., 2006. An extended performance reporting framework for social and environmental accounting. Business Strategy and the Environment, 15(5), pp.309-321. 